\title{
A FEMINIST REFLECTIVE ANALYSIS OF GENDER MAINSTREAMING IN YOUTH POLICY AND PRACTICE IN THE REPUBLIC OF MOLDOVA
}

\author{
Jane M. KELLUM1, Master in International Relations, \\ Independent Gender, Education, and Youth Consultant ${ }^{2}$ \\ Medford, Oregon, United States
}

\author{
DOI: https://doi.org/10.36004/nier.es.2020.1-09 \\ JEL Classification: K38, 019, 029, Y90 \\ UDC: 316.346.2(478)
}

\section{ABSTRACT}

This year, 2020, marks the 25th anniversary of the 1995 United Nations Fourth World Conference on Women in Beijing where gender mainstreaming was introduced. Since then, gender mainstreaming has come to be recognized as the inter-governmentally agreed strategy to achieve gender equality and female empowerment and involves integrating a gender perspective into all aspects of governmental policy, regulation, and budgeting, with an eye towards promoting equality between women and men, social inclusion, and eliminating discrimination in all its forms. Despite notable achievements, an important body of feminist scholarship reveals that gender mainstreaming faces many challenges. In this paper, I contribute to this body of knowledge by using a feminist reflective practice approach to analyze the gender mainstreaming process I undertook as part of the 2020 Comprehensive Youth Sector Analysis in the Republic of Moldova. Through this analysis, I identify a number of challenges that can be understood as part of the larger social construction of gender inequality and conclude that gender mainstreaming processes embody the same gender inequality and patriarchy that we encounter in our larger social structures. This, in turn, acts as one of the greatest threats to gender mainstreaming as an effective strategy to achieve gender equality.

Keywords: gender equality, gender mainstreaming, women's empowerment, reflexive practice, feminism.

Anul curent, 2020, marchează 25 de ani de la cea de-a patra Conferință Mondială privind femeile organizată la Beijing în 1995 sub auspiciile Organizația Națiunilor Unite, unde a fost introdusă abordarea de gen. De atunci, integrarea dimensiunii de gen a devenit o strategie, recunoscută interguvernamental, pentru obținerea egalității de gen și împuternicirea femeilor. Aceasta implică integrarea dimensiunii de gen în toate domenii ale politicii guvernamentale, a reglementărilor și bugetelor de stat, urmărind promovarea egalitătii între femei și bărbați, incluziunii sociale și eliminarea tuturor formelor de discriminare. În ciuda realizărilor notabile, o parte importantă a cercetărilor relevă faptul că integrarea dimensiunii de gen se confruntă cu mai multe provocări. În lucrarea de față, am contribuit la această totalitate de cunoștințe, folosind o abordare a practicii feministe reflective pentru a evalua procesul de integrare a dimensiunii de gen ca o componentă a Analizei Comprehensive a Sectorului de Tineret în Republica Moldova, la care am participat în 2020. Prin această analiză, am identificat o serie de provocări care prezintă o parte componentă a celei mai mari construcții sociale a inegalității de gen și constat că procesele de integrare a dimensiunii de gen cuprind în sine

\footnotetext{
1 C Jane KELLUM, $\bowtie$ janekellum@hotmail.com

2 Jane Kellum is an international gender, education, and youth consultant with over fifteen years of experience in diverse and complex contexts in Latin America and the Caribbean, West and East Africa, Southeast Asia, Middle East, and Central/Eastern Europe. She holds a B.A. in Political Science, Summa Cum Laude, from Tulane University (New Orleans, Louisiana, USA), and a Master's in International Relations with a concentration in Economics, Development, and Cooperation from the Universidad del Salvador (Buenos Aires, Argentina). Since 2016, Ms. Kellum has been an independent consultant providing her services to various international organizations and NGOs that include UN Women, UNICEF, the Caribbean Community (CARICOM), CARE International, Save the Children, Plan International, and Banyan Global. She is an experienced researcher, specializing in qualitative methods and topics related to education, youth development, child protection, gender, equity and equality, human rights, and social inclusion. She also specializes in gender analysis and sector-specific analysis and assessment related to education, youth, and children.
} 
aceeași inegalitate de gen și patriarhat pe care le întâlnim în structurile sociale mai mari. Totodată, aceasta constituie una dintre cele mai mari amenințări la integrarea dimensiunii de gen ca strategie eficientă pentru obținerea egalității de gen.

Cuvinte-cheie: egalitate de gen, gender mainstriming, împuternicirea femeilor, practică reflexivă, feminism.

В 2020 году отмечается 25-я годовщина четвертой Всемирной конференции Организации Объединенных Наций по положению женщин в Пекине 1995 г., положившей начало гендерному подходу. С тех пор учет гендерной проблематики стал признаваться в качестве согласованной на межправительственном уровне стратегии по достижению гендерного равенства и расширению прав и возможностей женщин, и предусматривает учет гендерной проблематики во всех областях государственной политики, регулирования и бюджетирования с целью обеспечения равенства между женщинами и мужчины, социальной интеграции и ликвидации дискриминации во всех ее формах. Несмотря на достигнутые успехи, значительное число исследований показывает, что учет гендерной проблематики сталкивается со многими проблемами. Данная статья внесет свой вклад в эту совокупность знаний путем использования подхода феминистской рефлексивной практики для анализа процесса учета гендерной проблематики, который я предприняла в рамках Комплексного анализа молодежного сектора Республики Молдова в 2020 г. С помощью этого анализа я выявила целый ряд проблем, которые можно понять как часть более широкой социальной конструкции гендерного неравенства, и делаю вывод о том, что процессы актуализации гендерной проблематики воплощают то же гендерное неравенство и патриархат, с которыми мы сталкиваемся в более крупных социальных структурах. Это, в свою очередь, является одной из самых серьезных угроз для учета гендерной проблематики в качестве эффективной стратегии достижения гендерного равенства.

Ключевые слова: гендерное равенство, гендерный мейнстриминг, расширение прав и возможностей женщин, рефлексивная практика, феминизм.

\section{INTRODUCTION}

Gender equality is the enjoyment of equal rights, responsibilities, and opportunities among women and men and girls and boys; it does not seek to make women and men the same, but that these equal rights, responsibilities, and opportunities are not dependent on being born either male or female (UN Women, n.d.). It is both a fundamental human right as enshrined in a number of international treaties and agreements, notably the International Covenant on Civil and Political Rights, the International Covenant on Economic, Social, and Cultural Rights, and Conventional on the Elimination of Discrimination Against Women (OHCHR, n.d.) and a powerful means to reduce poverty and advance development as a number of multilateral organizations (World Bank n.d. and the United Nations n.d.) affirm and a growing body of evidence confirms (Kabeer and Natali (2013), Nieuwenhuis et al. 2018). ${ }^{1}$ Gender equality has its roots in both feminist thought and practice, including the women's rights movement. Accordingly, redressing inequity and inequality that disproportionately impacts women through socially constructed power relations and structures in which men dominate remains at the heart of all efforts that seek to realize gender equality (Bacchi 2010:22).

UN Women's 2020 report, Gender Equality: Women's Rights in Review 25 Years After Beijing, illustrates that gains - such as global average gender parity in education and legal and regulatory reforms in 131 countries that support gender equality - have been made towards achieving gender equality (UN Women 2020a:4). These gains can be attributed to dedicated action by policy makers, including through gender mainstreaming $(\mathrm{GM})$, which is defined as "the integration of a gender perspective into the preparation, design, implementation, monitoring and evaluation of policies, regulatory measures and spending programs, with a view to promoting equality between women and men, and combating discrimination" (EIGE 2020). Indeed, a number of United Nations intergovernmental resolutions, mandates, and decisions

\footnotetext{
1 A complete literature review on this topic is outside the scope of the present study. The examples are illustrative in
} nature. 
that include the 1995 United Nations Fourth World Conference on Women in Beijing, the Sustainable Development Agenda 2030, and the Paris Agreement have affirmed that GM is the primary intergovernmentally-agreed, global strategy for achieving the goal of gender equality and empowerment of women and girls. Gender mainstreaming furthermore "moves gender equality and the empowerment of women from the margins to the mainstream of decision-making" (UN Women 2020b:2).

Nevertheless, UN Women's 2020 report on the state of gender equality illustrates that universal gender equality - including equal participation in politics, socioeconomic standing, and freedom from gender-based violence - continues to be out of reach with women predominately on the losing end (UN Women 2020a: 4-5). The still unrealized achievement of gender equality points to potential shortcomings of GM as the "most practical means to achieve gender equality and the empowerment of women" (UN Women 2020b:2).

\section{LITERATURE REVIEW}

A review of literature on challenges of GM in policy development yields a number of notable works. Straught (2003) argues that GM is equated with a specific machinery (e.g., staff and/or departments) within governmental institutions instead of being considered a core characteristic of good governance. Cavaghan (2017) examines the barrier of resistance by governmental staff and authorities to GM by comparing two gender mainstreaming policy cases implemented within the framework of the European Commission's Directorate General of Research between 2002 and 2006. Lombardo and Mergaert (2013) also examine the obstacle of resistance, specifically to gender training conducted as part of GM processes in policy-making.

Bacchi and Eveline (2010) provide extensive analysis of GM processes in policy development in countries that include Australia, Canada, and the Netherlands, illuminating dilemmas and challenges such as insufficient time and space for public servants to explore, learn, understand, and embrace GM and a narrow focus on "gender" mainstreaming that oftentimes ignores the diversity of women and the various compounded discrimination they may face based on other factors like ethnicity, gender identity, sexual orientation, and others. Reflecting on her own experience in the field of GM, Mukhopadhyay (2016a) analyzes how "feminist concerns with the political project of equality are being normalized in the development business as an ahistorical, apolitical, de-contextualized and technical project that leaves the prevailing and unequal power relations intact...Gender mainstreaming is being interpreted as getting rid of the focus on women, regardless of context." Mukhopadhyay (2016b) dives deeper into this challenge facing GM, describing it as being "streamed away into... bureaucracies."

A common thread within this body of research is the use of the feminist lens, independent of whether it was explicitly or implicitly employed to understand core challenges to GM in policy development. In other words, these scholars have sought to understand failings and challenges of GM to achieve gender equality by examining it from the standpoint of those whose particular lives are lived in oppression (i.e., women and girls) under a predominately male-dominated world (i.e., patriarchy). Most of these works examine the challenges from a third-person point of view with the exception of Mukhopadhyay (2016a; 2016b) who uses first-person inquiry of her own direct experience in GM to examine the obstacles that have undermined GM as a strategy globally. However, research conducted and published by gender practitioners-those conducting gender analysis and/or using other tools as part of a given policy development process-appears to remain scarce overall, thereby opening an important opportunity to contribute to this area of feminist investigation.

PURPOSE OF STUDY, THEORETICAL FRAMEWORK, AND METHODOLOGY

In this paper, I seek to contribute to the feminist scholarship that examines challenges to GM in policy development from a critical, first-person perspective. Specifically, I will analyze challenges that emerged during the GM process I led as part of the 2020 Comprehensive Youth Sector Analysis (CYSA) in the Republic of Moldova (RoM) ${ }^{1}$ using a feminist reflective practice approach.

\footnotetext{
${ }^{1}$ As the National Strategy for Youth Sector Development (NSYSD)'s operational period neared its completion and with eye towards better understanding gaps identified in the 2018 OECD Youth Well-being Policy Review, the Ministry of Education, Culture, and Research (MECR) requested UNICEF's support to conduct a CYSA in 2019. As part of its respective country program strategy and global mandate and in support of the National Strategy for Gender Equality in Moldova, the support of UNICEF aimed to advance gender equality in the youth development sector policy, strategy,
} 
Accordingly, I will conduct a case study of the CYSA in the RoM using an adapted theoretical framework that combines feminist theory and two related methodological approaches: reflective and reflexive practice. A feminist lens is one that allows a researcher to make inquiries based on where s/he stands in her/his life that has been socially constructed, notably allowing her/him to better understand lives of those lived under oppression and/or disadvantage, notably women and girls (Connolly 2018: 33). By nature, a feminist perspective is part of critical theory which is an approach to social inquiry that both "interprets the acts and the symbols of society in order to understand the ways in which various social groups are oppressed" and "examines social conditions to undercover hidden structures" while also making a "conscious attempt to fuse theory and practice...to bring about change in the conditions that affect our lives" (Seiler N.d.).

On the one hand, reflective practice is "thinking about and critically analyzing one's actions with the goal of improving one's professional practice" (Imel 1992: 2). On the other hand, reflexive practice, or reflexivity, goes further: it involves critical self-analysis that questions one's own values, thought processes, behaviors, assumptions and analyzes how this impacts what happens in a person's professional practice, relationships, and/or associated organizations (Bolton and Delderfield 2018: 14).

By approaching reflective and reflexive practice from a feminist perspective, Connolly $(2018: 31,33)$ explains that this type of critical self-analysis - or what she calls feminist reflective practice - of one's professional practice, "focuses on our being in the world, how we, as agentic practitioners in a stratified world, see that world...reflexive practice has to encompass a consciousness-raising element, rather than simply improve practice...it questions how this [stratified world of oppression] influences [our] practice and asks what [our] commitment to emancipation is? And how do [we] turn this into knowledge?" (Connolly 2018: 31,33).

Using this theoretical framework, I first conducted a reflective practice analysis of the gender analysis I completed as part of the CYSA by asking myself what challenges I experienced or observed during each stage or component of the GM process (e.g., CYSA and GM Terms of Reference; the gender analysis design, data collection, gender integration into larger CYSA, presentation of final results, etc.). I then conducted a reflexive practice analysis using CARE International's Gender Equality Framework (GEF) as tool to interpret the challenges. The GEF framework posits that equality can only be realized if we transform discriminatory structures, change power relations, and build female agency. The inverse then tells us that gender inequality thrives in a context where structures include discriminatory social norms, institutions, policies, and practices (whether intentional or not), gendered relationships are characterized by power imbalances, and women and girls do not have fully realized agency in regards to their confidence, self-esteem, aspirations, abilities, education, etc. (CARE International 2018:7).

RESULTS AND DISCUSSION

The feminist reflective practice analysis I undertook to examine the GM mainstreaming process I led as part of the CYSA in the RoM was not a straightforward endeavor. My final theoretical approach, in terms of how to interpret the findings of my reflective analysis, only emerged during the actual analytical exercise itself. The initial analysis I undertook of the CYSA GM process began as a mechanical process using a matrix I created based on a project management approach to learning -lessons learned. For each GM process component (e.g., CYSA terms of reference, GM terms of reference, data collection, etc.), I sought to brainstorm key challenges and how they were overcome in the process as way to produce new practical "how-to" insights for gender practitioners, including myself. However, as the matrix began to fill up with the challenges across the various components of the GM process itself, I noticed key patterns emerging that interestingly, though not surprisingly, were reminiscent of key findings and conclusions of the actual gender analysis of the youth sector I conducted (e.g., limited prioritization of gender in the GM process, harmful gender norms

and programs by ensuring the completion of a gender-sensitive CYSA. To this end, UNICEF with the support of UN Women recruited the author of the present article as an international consultant to ensure comprehensive gender mainstreaming in all components of the CYSA. 
negatively impacting the GM process, and limited capacity and political will to realize the GM process). ${ }^{1}$ I realized I needed the critical theoretical lens to accurately interpret the socially constructed patterns of power imbalance and inequality that were emerging within the GM process itself. Accordingly, the feminist reflective practice approach emerged as my theoretical framework.

Through this critical self-inquiry-based analysis, I identified, analyzed, and interpreted three main challenges of the CYSA GM process.

Reflection

(1) GM as separate within the CYSA process: A comparative review of the original CYSA Terms of Reference (TOR) published by UNICEF with the TOR for the GM consultancy published by UN Women clearly reveal a strong priority on ensuring gender was fully mainstreamed into the CYSA process. Despite the priority, gender was still being approached as separate from the larger CYSA. For example, the CYSA TOR did not require applying organizations to propose and ensure gender expertise on their team but rather mentioned that a consultant would be engaged on a separate contract but expected to collaborate closely with the organization commissioned to complete the larger CYSA. While many advantages of this approach exist such as autonomy for the gender consultant to conduct an objective gender analysis and integration into the larger CYSA, it also establishes a precedent for gender to not actually be mainstreamed but remain a stand-alone exercise outside of the larger CYSA.

Indeed, the CYSA TOR envisioned the gender analysis as a separate chapter in the proposed outline of the CYSA report. This was an aspect on which I resisted during the GM process since having gender as separate contradicts the tenet on which GM stands: GM seeks to move gender into the "mainstream" of all policy development. I was largely successful in my lobbying efforts to fully integrate gender into the larger CYSA process, including the CYSA report and related presentations of findings. Although much of my genderrelated contributions to each chapter of the CYSA report were included, much of it was cut under the premise of both saving limited space and avoiding distraction from the larger objective of the CYSA. In the end, I drafted a comprehensive annex that outlined all key findings, conclusions, and recommendations that were included in the main body of the CYSA as well as additional gender-related outcomes of the gender analysis process. Admittedly, the annex provided an opportunity to expand on the gender analysis results while also resolving space limitations. Nevertheless, despite reiterating the message that gender was not separate but an integral part of the CYSA to drive home this important message in both the annex and during my separate presentation of results at the CYSA National Validation Workshop in February 2020, the gender annex inclusion sent a strong message that gender is separate.

(2) Time constraints on the GM process: Insufficient time to systematically complete the GM was a challenge that crossed all stages of the process. The original calendar envisioned I make three mission trips with the first dedicated to integrating with the larger CYSA team and finalizing integration of gender into the inception report, CYSA methodology, and qualitative research tools. This mission trip would have also included an initial validation exercise with the Ministry of Education, Culture, and Research (MECR) to approve the inception report, methodology, and tools. By the time I was on-boarded as the gender consultant, this stage of the CYSA was already completed, thereby depriving the GM process a crucial legitimizing step to ensure gender was a fully integrated component of the larger CYSA process. The organization that was commissioned to conduct the CYSA had also made significant progress in completing the desk review portion of the exercise and was going to begin interviews within a couple of days of our initial call. Although I rose to the challenge and within three days had done a comprehensive and systematic review of the inception report, methodology, and tools, the original documents had already been approved

\footnotetext{
1 The four key conclusions of the youth sector gender analysis I completed as part of the GM process were (1) Gender equality and social inclusion are not priorities in youth-related policies and programs; (2) Persistent intersectionality - also known as compounded discrimination and vulnerability - impacts several groups of especially vulnerable female and male youth and adolescents; (3) Harmful gender norms-that include what it means to be masculine or feminine and how sexuality and reproductive issues are addressed in society - are at the root of most pressing issues faced by male and female youth; (4) Youth sector governmental authorities [i.e., relevant Ministries and local government entities] lack financial and technical capacity and the political will to effectively mainstream gender into youth policy (Kellum 2020: 90-96).
} 
and the stage was set for gender to be sidelined.

Similar time constraints plagued the entire process. For example, gender-related primary data collection was not specifically anticipated as part of the gender analysis. The only opportunity to conduct primary research was during the three consultation workshops that were used to present preliminary findings and receive feedback of the first draft report in December 2019. Similarly, I only received the first draft report as I boarded the plane to participate in the workshops, meaning the consultation workshops were based on a draft report without a thorough gender review. Again, I worked together with the larger CYSA team to ensure the consultation workshop presentation included key gender findings, preliminary conclusions, and recommendations. However, undoubtedly quality of the gender integration suffered under time limitation.

(3) Direct resistance to GM: Direct resistance to the GM process is another challenge that manifested itself in a number of ways throughout the larger CYSA process. One example included expressed discomfort among some stakeholders about including analysis of young LGBTI people or examining intersectionality compounded discrimination - and how this impacted specific groups of vulnerable and/or marginalized male and female youth and their interaction with the youth sector. However, I overcame these obstacles and was successful in including these aspects in the CYSA.

Another example was gender discriminatory jokes and attitudes expressed by male FGD participants during the consultation workshop sessions I facilitated in December 2020. These included statements like "there is too much focus on supporting young women" and "men are born leaders but women would have to be given training to be a leader." I immediately challenged these sexist beliefs by calling out the faulty premises on which their beliefs and attitudes were based.

A third example of resistance was particularly notable as a direct assault on GM as a means of achieving gender equality and necessary component of policy development. The incident took place at the CYSA National Validation Workshop in February 2020. After I made the final presentation of the workshop focused on the gender-related findings, conclusions, and recommendations, the workshop facilitator initiated the question and answer session. The first person to raise his hand was a male representative of an international organization. What proceeded to happen, I argue, is that he employed a number of logical fallacies often wielded by people to manipulate others and information and which is considered a breach of ethics in public speaking (Barton and Tucker 2020). In this case, he did so to undermine not only me as a gender specialist but also GM as a legitimate process in the Moldovan youth sector policy development and gender inequality as a current problem in the RoM.

He began speaking in Romanian but then insisted on speaking English, even though I was the only person who was a native English speaker in the room. I had a translator, so it was not a necessary step to ensure I understood. He then publicly congratulated me on my presentation of the CYSA gender mainstreaming results - public praise that not unimportantly, as we will see later in my reflexive analysis, was preceded by him leaning over my translator to tell me privately as the workshop facilitator opened up the Q\&A to say "you need to be taken out for a beer for that presentation." The tone of our interaction quickly changed, however, as he launched into his intentional attack.

He first began by employing the ad hominem ${ }^{1}$ logical fallacy by seeking to publicly humiliate me as the gender specialist by asking if I knew Valentina Vladimirovna Tereshkova. ${ }^{2}$ When I responded that I did not, he shook his head, making an exaggerated show of scolding me for not knowing that she was the first female to travel to space and also from the Soviet Union during the time when the RoM was part of the U.S.S.R. Using this fallacy, he sought to discredit my view and opinions set forth as a gender and women's rights specialist by showing that I have some personal flaw, which in this case, was "ignorance" of notable women in the

\footnotetext{
${ }^{1}$ Ad hominem is a logical fallacy described as when "arguer attacks his or her opponent instead of the opponent's argument" (The Writing Center at UNC Chapel Hill n.d.).

2 Valentina Vladimirovna Tereshkova was the first and youngest women to ever travel to space in 1963. Although she is not Moldovan but Russian, Moldova was part of the U.S.S.R during this time.
} 
Moldovan context. He simultaneously used tokenism ${ }^{1}$ by erroneously equating her individual achievement with the existence of gender equality and empowerment for all Moldovan women.

He employed the false equivalence ${ }^{2}$ fallacy by erroneously equating the CYSA GM process, specifically key findings in the CYSA that point to a gender inequal socio-cultural context in which the youth sector is situated, as a "foreign" ideology being pushed on Moldovans similar to how the foreign communist ideology was pushed during the Soviet era. However, unlike communism, which is a socio-political ideology, gender equality and the strategies to achieve it are enshrined within the framework of fundamental human rights inherent to all humans.

He used the tu quoque $e^{3}$ fallacy in the form of whataboutism 4 to divert attention from the context at hand- the RoM. Specifically, he stated, "What about the United States? They have gender-based violence? Why should we be focusing on that in Moldova when it exists everywhere?" In this case, he erroneously appealed to an imaginary hypocrisy on my part, since I am a professional specializing in gender who also happens to be from the United States where GBV exists as well. He also was seeking to divert attention from the topic at hand which was gender inequality in Moldova not the situation of GBV in the United States. In the course of his intervention, he also described naming particularly vulnerable groups of youth as part of the GM process as divisive as opposed to inclusive, revealing a bias against basic tenets of GM.

By the time he had finished his intervention, somewhere between 30 and 45 minutes - almost the entirety of the time allocated to the question and answer session - had passed. Although some of his comments were not aimed directly at my contributions to the CYSA, most of his comments made their way back to disputing the GM findings and conclusions in the CYSA. He had essentially utilized the question and answer session of the CYSA National Validation Workshop as a platform to undermine the GM process. Unfortunately, my reaction to this egregious resistance to GM was not what I would have expected of a gender specialist: I did not respond at all. To say I was shocked, humiliated, and fully unprepared for such an assault on me as a professional and on my field of expertise overall would be an understatement. A few months needed to pass for me to fully understand my non-reaction; this will be analyzed further below using a reflexive practice approach.

\section{Reflexivity}

On the surface, the three challenges analyzed above may appear to have emerged because of one-off institutional logistical issues or isolated incidences of gender naysayers using faulty logic. However, examining them from a critical reflexive lens reveals their emergence during the GM process to be part of the much larger problem of gender inequality that the GM seeks to redress. To do this, I will now analyze the identified challenges using CARE International's Gender Equality Framework.

The first challenge - situating gender as separate versus an integral part of the larger CYSA - and the second challenge - time constraints - can both be understood in the context of discriminatory structures (policies, practices, norms, etc.) according to the CARE International framework. To be clear, I am not suggesting the contracting international organizations and/or the organization commissioned to conduct the CYSA of intentionally sidelining gender from the larger CYSA or shorting the GM process activities of sufficient time. Rather, I argue that institutional policies and practices within their and other influential and relevant organizations locked them into these patterns.

To understand how this works, understanding discrimination is essential. According to Pincus (2000: 1), discrimination operates at three levels: individual, institutional, and structural. While both individual and institutional discrimination is an intentional discrimination against someone or a group of individuals based on gender, race, ethnicity, or any other factor, structural discrimination "refers to the policies of dominant race/ethnic/gender institutions and the behavior of the individuals who implement these policies and

\footnotetext{
1 Tokenism is a logical fallacy that is "interpreting a token gesture as an adequate substitute for the real thing." (Bennet, B. 2020)

${ }_{2}^{2}$ False equivalence is a logical fallacy that "simultaneously condemns and excuses both sides in a dispute by claiming that both sides are (equally) guilty of inappropriate behavior or bad reasoning." (Thompson, B. n.d.)

3 The tu quoque logical fallacy is underpinned by claiming some type of hypocrisy on the part of one's adversary to discredit claims made by the adversary. (Stanford University 2020)

${ }^{4}$ Whataboutisim is "bringing up of one issue in order to distract from the discussion of another." (Rational Wiki 2020)
} 
control these institutions, which are race/ethnic/gender neutral in intent but which have a differential and/or harmful effect on minority race/ethnic/gender groups." Applying this definition of structural discrimination to the GM process in the CYSA, certain institutional policies, practices, and/or capacities (or more accurately a lack thereof) were not in place to "discriminate" or impede the GM process directly but did so in very real ways.

Regarding the "gender as separate" challenge, a general lack of gender capacity (i.e., knowledge, knowhow, and experience to effectively integrate a gender perspective into the CYSA process) among national institutions in Moldova likely led to the decision by UNICEF to present the GM as separate in the initial CYSA TOR. Likewise, the perceived inability of youth sector stakeholders to fully accept and understand gender analysis because of existing gender attitudes and understanding of gender equality (e.g., persistent misunderstanding in Moldova that gender means making women and men the same) likely contributed to the various decisions to present gender as separate in the CYSA process. In other words, structures in the form of gender and social norms are at the root of this impediment to the GM process.

In the case of time constraints, for example, cumbersome procurement and human resources policies of the international contracting agencies in combination with bureaucratic approval processes by relevant governmental stakeholders in the RoM likely delayed my initial onboarding. Similarly, institutional budgeting decisions of the international contracting agencies and, in turn, financial constraints likely contributed to a reduced scope of work for the GM process, leading to insufficient time allocated to conduct primary research in-country. These same policies and practices pressured the organization commissioned to conduct the CYSA, creating a time crunch for them that ultimately was passed on to the GM component given its ultimately "separate" and inherently secondary status within the larger CYSA process. While unintentional, these structural factors negatively impacted the GM process.

Turning to the incident that occurred at the National Validation Workshop, I have had time to conduct a deep and unsettling reflection to understand why I, as an international gender specialist, did not respond to the not only blatant sexism but also fallacious logic employed. To understand the dynamic that took place at the workshop, all three levels of CARE International's GEF are useful. In regards to agency, I am a woman. I am a highly educated forty-year old woman who has worked in the area of gender equality and mainstreaming globally for 10+ years. Despite my education and experience, I felt much of my "agency" become fragile as this man systematically and quite skillfully demeaned me for not knowing a renowned Soviet woman, dismissed my research findings as merely ideological hyperbole, and equated me to a hypocrite for having the audacity to come to Moldova to point out problems of violence against women while being a woman from another country where gender-based violence is also prevalent. On the hand, my agency, notably confidence in my own abilities as a gender specialist, was undermined by this man. On the other hand, I was not technically prepared to coherently counter each of his faulty arguments. At the same time, I gave him a great deal of power in this moment; what would have counted was not necessarily the exact articulation I used but the intention to call out sexism in the moment of its occurrence. At the same time, my agency was my own because, ultimately, I made a conscious decision to not respond to him because alongside these feelings of wavering confidence and unpreparedness was a firm belief that I had a responsibility to not take up more time as another foreign "expert" in a space that was clearly intended for Moldovans to share their experience and feedback about a policy that would affect their lives. The latter I believe was an attempt on my part to be reflexive in my practice by keeping in check the privilege and power that can come in the form of being an international consultant.

At the same time, another issue of power imbalance was also at play in this scenario. The relations level of CARE's GEF is useful to understand this better. The other person in this scenario was a foreign male, working for an international organization in an influential advisory position to the Moldovan government. Each of these factors added layers to the power imbalance between him and me. However, the mere fact that he was a foreign man working in an influential position for an important international organization does not in itself cause the power balance. It was his decision to use these characteristics to tip the balance of power in his favor, and, in turn, "put me in my place" and ultimately show dominance. This happened through the acts, attitudes, and behaviors he employed during his 30-45 minute intervention: minimization of all my professional efforts and work that culminated in the final presentation by inappropriately telling me that I "deserved to be taken for a beer"; using language as power by insisting on speaking in English to ensure I clearly understood his message and that nothing was lost in translation; using faulty argumentative 
techniques to manipulate others in the audience, publicly humiliate me, and undermine the overall GM process I undertook in the CYSA.

If we look at this scenario from the structural perspective, two interesting questions emerge: (1) How does a man that clearly does not support gender mainstreaming end up in such as influential position in an organization that professes gender equality as a guiding principle? and (2) Why were my female colleagues from other international organizations mostly silent in response as I was? Exploring the first question from the structural lens points to the very real possibility that institutional policies, practices, and culture either directly or indirectly support these types of attitudes and allow them to co-exist within the organization that on paper is a beacon of equality. Regarding the second question, I had the opportunity to reflect together with a couple of my female colleagues after the workshop. They were as indignant as I was about what happened. They explained that the reason they did not respond themselves and why the one response by another female colleague from a different organization was relatively reserved was because they feared some type of professional retaliation. They explained that the person was influential in upper levels of government, and accordingly, they could not be certain of whom he knows and/or what he would say about them had they publicly confronted him at the workshop. The latter points to a larger norm within both national and international organizations in Moldova of silencing female and feminist voices. Returning again to power dynamics, it also points to an additional area for my own reflexive practice on issues related to power and privilege to understand when I should remain silent as an international consultant and when I should use that same position to give voice to female colleagues in their home countries where they may not feel they have voice due to structural social constraints.

\section{CONCLUSIONS}

The challenges to the GM process that emerged during the CYSA are not isolated obstacles that can be resolved using solely functional or technical solutions. Instead, my feminist reflective practice analysis reveals how the specific challenges of the GM process encountered are situated within a larger social structure of gender inequality and patriarchy characterized by discriminatory structures, gendered power relations, and women's agency that, in many ways, continues to be influenced by men. This reveals that GM processes embody the same gender inequality and patriarchy that we encounter in our larger social structures, which, in turn, is one of the greatest threats to GM as an effective strategy to achieve gender equality. Because GM is inseparable from the larger social structure, we need new strategies to ensure structural, relational, and agentic factors do not continue undermining the effectiveness of GM.

This warrants increased research of the GM process from a critical, feminist lens using reflexive practice and other relevant methodological approaches to better understand how these blockages manifest themselves and how best to overcome them. It will require new approaches to GM that inherently involve transforming resistance to GM in all forms whether structural or direct, intentional or unintentional into a full embracing of GM. This will, by necessity, involve all institutions that play a role in policy development globally (e.g., international and regional organizations, national governments, donors, and others) to comprehensively examine all structural aspects that make up their institutions (policies, practices, capacities, culture, etc.) and determine how they support or undermine GM. It will require achieving more balanced power dynamics among the men and women who are supporting policy development nationally and internationally. It will also involve opening even more communities of practice for gender practitioners to sharpen our skills to effectively confront resistance to GM in the moment it occurs. We, as gender practitioners, must continue to advocate for increased preliminary and ongoing activities that go beyond gender training to include long-term critical reflection work, embedded gender equality specialists and facilitators, and on-going coaching and advising in governmental institutions to transform relevant stakeholders in policy development processes into champions of the GM process. The time is now as we take stock of the last 25 years since GM was introduced into the global discourse and practice at the Fourth UN Women's Conference in Beijing in 1995. Without intentional inclusion of approaches that seek to prepare the policy development context for GM, we risk the continued mediocre results of GM, namely unrealized universal gender equality and women's empowerment.

\section{REFERENCES}

1. BACCHI, Carol. Gender/ing impact assessment: Can it be made to work? In: C. BACCHI, and J. EVELINE (eds). Mainstreaming politics: Gendering practices and feminist theory. Adelaide: University of 
Adelaide Press, 2010, pp. 17-39. e-ISBN 978-0-9806723-8-1 [citat 15 aprilie 2020]. Disponibil: http://library.oapen.org/bitstream/id/d29d407d-053e-4797-b07923d80d1baf3a/560246.pdf\#page $=109$

2. BACCHI, C., EVELINE, J. Mainstreaming politics: Gendering practices and feminist theory. Adelaide: University of Adelaide Press, 2010. e-ISBN 978-0-9806723-8-1 [citat 20 aprilie 2020]. Disponibil: http://library.oapen.org/bitstream/id/d29d407d-053e-4797-b07923d80d1baf3a/560246.pdf\#page $=109$

3. BARTON, K., TUCKER, B. Exploring public speaking. Galileo Open Learning Material. 2020 [citat 20 aprilie 2020]. Disponibil: https://oer.galileo.usg.edu/communication-textbooks/1/

4. BENNET, B. Tokenism. Logically Fallacious. 2020 [citat 20 aprilie 2020]. Disponibil: https://www.logicallyfallacious.com/logicalfallacies/Tokenism

5. BOLTON, G., DELDERFIELD, R. Reflective practice: an introduction. In: G. BOLTON, R. DELDERFIELD. Reflective practice: Writing and professional development. London: Sage Publishing Ltd, 2018 [citat 20 aprilie 2020]. Disponibil: https://uk.sagepub.com/sites/default/files/upmbinaries/32441_01_Bolton_3e_Ch_01.pdf

6. CARE International Gender equality and women's voice guidance note. 2018 [citat 20 aprilie 2020]. Disponibil: https://insights.careinternational.org.uk/media/k2/attachments/Gender_equality_womens_voice_G uidance_Note_2018.pdf

7. CAVAGHAN, R. Making gender equality happen: Knowledge, change, and resistance in EU gender mainstreaming. New York-London: Routledge, 2019. 230 p. ISBN 9780367371845.

8. CONNOLLY, B. Reflective practice and the feminist lens: The other side. In: The Irish Journal of Adult and Community Education. 2018, pp. 23-35. ISSN 0790-8040 [citat 21 martie 2020]. Disponibil: https://files.eric.ed.gov/fulltext/EJ1197434.pdf

9. EUROPEAN INSTITUTE FOR GENDER EQUALITY. What is gender mainstreaming? 2020 [citat 11 aprilie 2020]. Disponibil: https://eige.europa.eu/gender-mainstreaming/what-is-gender-mainstreaming

10. KELLUM, J. Gender mainstreaming in the CYSA. In: O. GAGAUZ et al. Comprehensive Youth Sector Analysis. National Institute for Economic Research, Ministry of Education, Culture, and Research, UNICEF, UNFPA. Chisinau: INCE, 2020, pp. 90-101. ISBN 978-9975-3378-5-4.

11. IMEL, Susan. Reflective practice in adult education. ERIC Digest. 1992, no. 122 [citat 15 februarie 2020]. Disponibil: https://files.eric.ed.gov/fulltext/ED346319.pdf

12. KABEER, Naila, NATALI, Luisa. Gender equality and economic growth: Is there a win-win? IDS Working Paper 417. Brighton: Institute of Development Studies, 2013, february. ISSN 2040-0209 [citat 14 martie 2020]. Disponibil: http://www.lse.ac.uk/gender/assets/documents/research/choiceconstraints-and-the-gender-dynamics-of-lab/Gender-Equality-and-Economic-Growth.pdf

13. LOMBARDO, Emanuela, MERGAERT, Lut. Gender mainstreaming and resistance to gender training: a framework for studying implementation. In: NORA-Nordic Journal of Feminist and Gender Research. 2013, december, pp. 296-311 [citat 20 aprilie 2020]. Disponibil: https://eige.europa.eu/sites/default/files/art_gt_resistance_nora_2013_copy.pdf

14. MUKHOPADHYAY, M. Mainstreaming gender or "streaming" gender away: Feminists marooned in the development business. In: W. HARCOURT (eds). The Palgrave Handbook of Gender and Development, 2016a. London: Palgrave Macmillan, 2016, pp. 77-91 [citat 16 februarie 2020]. Disponibil: https://link.springer.com/chapter/10.1007/978-1-137-38273-3_6

15. MUKHOPADHYAY, M. Mainstreaming gender or "streaming" gender away revisited. In: W.

HARCOURT (eds). The Palgrave Handbook of Gender and Development. London: Palgrave Macmillan, 2016, pp. 132-142 [citat 16 februarie 2020]. Disponibil:

https://link.springer.com/chapter/10.1007/978-1-137-38273-3_10

16. NIEUWENHUIS, R. et al. Gender equality and poverty are intrinsically linked: a contribution to the continued monitoring of selected sustainable development goals. Progress of the World's Women. Discussion Paper no. 26. New York: UN Women, 2018, december [citat 20 aprilie 2020]. Disponibil: https://www.unwomen.org//media/headquarters/attachments/sections/library/publications/2018/discussion-paper-genderequality-and-poverty-are-intrinsically-linked-en.pdf?la=en\&vs=4100 
17. PINCUS, F.L. Discrimination comes in many forms: Individual, institutional, and structural. 2000 [citat 20 aprilie 2020]. Disponibil: https://media.lanecc.edu/users/martinezp/250\%20CRG/Discrim.pdf

18. Whataboutism. Rational Wiki Website [citat 11 aprilie 2020]. Disponibil: https://rationalwiki.org/wiki/Whataboutism

19. SEILER, Robert M. Human communication in the critical theory tradition. University of Calgary [citat 20 aprilie 2020]. Disponibil: https://people.ucalgary.ca/ rseiler/critical.htm

20. STANFORD UNIVERSITY. Fallacies. Stanford Encyclopedia of Philosophy. 2020 [citat 15 martie 2020]. Disponibil: https://plato.stanford.edu/entries/fallacies/

21. STAUDT, K. Gender mainstreaming: Conceptual links to institutional machineries. In: S. RAI (eds). Mainstreaming gender, democratizing the state? Manchester: Manchester University Press, 2003, pp. 40-66. eISBN 9781526127494. [citat 20 aprilie 2020]. Disponibil: https://www.manchesteropenhive.com/view/9781526137494/9781526137494.00011.xml

22. THOMPSON, B. False equivalency [citat 6 februarie 2020]. Disponibil: https://www2.palomar.edu/users/bthompson/False\%20Equivalency.html

23. UNITED NATIONS POPULATION FUND. Gender equality [citat 16 ianuarie 2020]. Disponibil: https://www.unfpa.org/gender-equality

24. UNITED NATIONS. Gender equality [citat 20 aprilie 2020]. Disponibil: http://www.un.org/en/sections/issues-depth/gender-equality/index.html

25. UNITED NATIONS HUMAN RIGHTS OFFICE OF THE HIGH COMMISSION. Women's human rights and gender equality. [citat 20 aprilie 2020]. Disponibil: https://www.ohchr.org/en/issues/women/wrgs/pages/wrgsindex.aspx

26. UN WOMEN. Concepts and definitions. [citat 17 februarie 2020]. Disponibil: https://www.un.org/womenwatch/osagi/conceptsandefinitions.htm

27. Gender equality: Women's rights in review 25 years after Beijing. New York: UN Women, 2020 [citat 27 aprilie 2020]. Disponibil: https://www.unwomen.org//media/headquarters/attachments/sections/library/publications/2020/gender-equality-womensrights-in-review-en.pdf?la=en\&vs=934

28. Gender mainstreaming: A global strategy for achieving gender equality \& the empowerment of women and girls. New York: UN Women, 2020 [citat 12 aprilie 2020]. Disponibil: https://www.unwomen.org/-/media/headquarters/attachments/sections/library/ publications/2020/gender-mainstreaming-strategy-for-achieving-gender-equality-andempowerment-of-women-girls-en.pdf?la=en\&vs=3849

29. WORLD BANK. Gender equality for development. A Development Impact Evaluation Brief [citat 20 aprilie 2020]. Disponibil: https://www.worldbank.org/en/research/dime/brief/dime-genderprogram

30. THE WRITING CENTER AT UNIVERSITY OF NORTH CAROLINA AT CHAPEL HILL. Tips and Tools: Fallacies - The Writing Center at UNC Chapel Hill [citat 11 februarie 2020]. Disponibil: https://writingcenter.unc.edu/tips-and-tools/fallacies/

\section{ARTICLE HISTORY}

Received 18 May 2020

Accepted 04 June 2020 